\title{
THE INFLUENCE OF THE LEXICAL AND GRAMMATICAL COMPONENT OF SPEECH ON THE FORMATION OF SPEECH COMPETENCE OF YOUNGER AD- OLESCENTS IN PRIMARY SCHOOL
}

\section{O. Hubar}

In the article, the author points out the need for the development of a speech personality in educational institutions as a prerequisite for the development of harmonization of the personality, its successful socialization in society. Modern documents and regulations indicate exactly this. A number of statistical data is also provided on the insufficient level of development of the adolescents' speech competence as a component of the communicative competence, which in turn creates unfavorable conditions for the adolescent's socialization and his/her adaptation in society.

The article also examines the features of the development of the lexical and grammatical component of the speech of younger adolescents in the conditions of primary school as a necessary component of the speech competence formation. The necessity of developing a special speech environment in a school is substantiated, the participants of which should be both objects of educational influence (adolescents) and teachers, specialists working in the educational space of a basic school. According to the results of the experiment, the peculiarities of the development of the lexical and grammatical aspects of speech of adolescents, studying in the inclusive environment of the primary, school are determined. The analysis of the influence of the level of formation of the lexical and grammatical aspect of speech on the formation of negative character traits in adolescents is carried out. The necessity of correction of speech disorders in adolescents has been proved in order to prevent difficulties in the educational process and socialization of the personality. These facts, in turn, prove the need for active speech therapy support for younger adolescents in a basic school environment

Keywords: teenager, speech competence, speech competency, personality, self-development, school environment

Copyright (C) 2021, O. Hubar.

This is an open access article under the CC BY license (http://creativecommons.org/licenses/by/4.0).

\section{Introduction}

Entrance of the younger generation in the dynamic society provides competitive activity in social life, increasing the role of competence and formation of the competent personality of pupils under conditions of an educational institution. In realities of the modern world the system of education and educational process in particular are transforming, because the crucial role in formation of the personality of a younger human, adolescent, is given to them.

Directions of solving today challenges are determined by the National strategy of the education development in Ukraine for the period till 2021, such as: modernization of content, structure and organization of education, based on the competence approach [1], so elaboration of the competence paradigm of education, formation of its new model. Introduction of a new educational model at secondary educational institutions, based on the competence approach, is realized at the expanse of determining key learning competences, accepted as Recommendations of the European parliament and European Council. One of leading places among them is occupied by communication in native and foreign languages as means for mastering different communication forms, important for work, socialization and adaptation to social conditions $[2,3]$.

As far as free use of language and speech is a prerequisite of personal development and socialization, the language and speech competences are necessary conditions for acquiring competences in all life spheres of a subject [4].

The speech competence structure is interpreted by us as the integrity of three components: speech experience, knowledge about language, hearing of language, each of which gains the communicative directionality and correspondent content. So, disorders of its components or obstacles, faced on the way of their development, result in problems in the adolescent's personal development that in its turn is reflected on the level of self-esteem and socialization. Thus, the problem of formation of the language, speech competences remains important during the whole learning term. Their formation is actualized in intermediate periods - on the boundary between primary and secondary, secondary and senior classes, - because there is a threat of losing or inhibiting already developed knowledge, acquired abilities and skills, caused by didactic, psychological and methodical factors.

The research topicality is intensified by the fact that school (5-9 classes) is a base of successive development of the communicative competence, which component is the speech one, but younger adolescents under conditions of changing the educational environment (transfer to the secondary school), under the influence of a series of personal formations, interaction with surroundings and certain speaking defects undergo complications in its formation that, in its turn, results in problems in communication, fixation on own shortcomings, 
decrease of self-esteem, learning success, refusal of communication and so on. Thus, the importance of the speech competence in younger adolescents in society arises in the new educational perspective and needs detail research of the influence of one of its components lexical-grammatical side - on its formation under conditions of secondary school.

\section{Literary review}

Scientific interest to adolescents' speech was manifested by linguists, pedagogues, speech therapists, psychologists, studied it at different levels: physiological bases of speech [5]; interconnection between thinking and speech, psychological aspects of speech [6]. Researches of age peculiarities of younger adolescents were conducted by generations of scientists [7]. But these categories remain topical for today that is caused by the growing role of communication in the modern information society, requirements to its quality, speech image, based on correct and expressive speech that forms a first impression about a person, and dependence of adolescents' speech competence formation. This statement is proved by the study by N. Gujvanyuk, S. Ermolenko, O. Tsaryk, who indicate the necessity of using material, connected with the internal world of a child, his/her emotional condition, surrounding world, studying the methodological aspect of formation of schoolchildren's oral and written speech culture [8]. Investigating the development of the lexical component of speech, K. Stefanyshyn accents the necessity to teach school pupils to orient in concrete speech situations, to select content and speech means according to a situation, to master rules of speech behavior under different communication conditions together with language theory [9].

The analysis of psychological-pedagogical literature testifies that foreign scientists have determined and differentiated the terms "competency" and "competence". Competencies are components, necessary for the communication competence (linguistic, sociolinguistic, discourse, strategic, sociocultural and social) [10]. Based on interpretation of the notions in the European educational system, Ukrainian researchers realized a deeper analysis of their content according to the Ukrainian linguistic system [11].

Questions of competence in native science are in the first turn connected with the notion of communicative competence as knowledge or ability to effective communication and correlates with key pupils' key competences [12].

Linguodidactic aspects of formation of the pupils' and students' communicative competence as an interdisciplinary phenomenon in teaching Ukrainian are investigated in $\mathrm{PhD}$ and doctoral theses by N. Holub [13]., T. Kostolovych [14]., I. Chebotarova [15]. They consider the competence directionality of the learning-upbringing native language process as the most favorable educational environment for speech competence development under today conditions.

But despite the essential number of scientificmethodical studies, devoted to teaching language, speech, socialization of adolescents, trials to trace an interconnection between the speech competence formation level as a precondition of speech personality de- velopment and the speech competency and its components formation level of younger adolescents in the educational environment of secondary school have not been realized for today, so we find it necessary to pay attention to this working direction.

\section{Research aim and tasks}

The research aim is to study the condition and to determine the speech competence formation level of younger adolescents in the educational environment of secondary school.

The following tasks were set for attaining the aim:

1) to determine criteria and indicators of speech competence formation,

2) according to separated criteria and indicators, to elaborate a method of their diagnostics;

3) to determine the influence of lexicalgrammatical component formation on the speech competence formation level.

\section{Materials and methods}

The method of diagnosing the speech competence of younger adolescents is elaborated, taking into account age standards of speech development, consisted of five blocks according to the number of components of the speech-communicative competency. Each of diagnosing blocks consisted of a series of tasks for revealing the level of speech competence components: informationprosodic, phonetic-phonemic, lexical-grammatical, diamonologic and psychological. Tasks, included assessment criteria, according to which the sum of points for quality of each task realization, have been developed for them. The tasks were based on the content of the school program for 12-year school of secondary educational institutions on the subject "Ukrainian language and literature", accepted by MES of Ukraine (of 23.12.2004) [16].

The elaboration of the own investigation method for the adolescents' speech competence needed developing diagnostic tasks for each indicator of determined criteria. The method is based on techniques of speech examination and methods of diagnosing speech disorders of schoolchildren, traditional for pedagogy, with using neuropsychological methods. Traditional diagnosing methods of studying oral speech are directed on revealing its quality and quantity characteristics (formation of lexical and grammatical sides). At the same time they needed modification and adaptation according to the studied category.

The study of the speech competence formation level was conducted during 2017-2020. It included 634 pupils of younger adolescent age (5, 6, 7 classes) under conditions of secondary educational institutions of Poltava, Kremenchuk and Gorishny Plavny. Children, whose parents gave consent to the participation in the experiment and personal data processing, were involved into the examination.

\section{Research results and their discussion}

Among 634 studied pupils of 5-7 classes of secondary school, 187 pupils $(29.4 \%)$ demonstrated the high speech competence formation level, and the low one was revealed in $148(23.3 \%)$. 
Let us stop more detail on the results, obtained at examining the lexical-grammatical aspect of adolescents' speech by a series of specially selected tasks individually, providing the following levels of help (repetition of instructions; explication of a task with an answer example; demonstration of an answer with an explication), some of them provided visual material.

The aim of the tasks was to determine the vocabulary volume and the grammatical component formation level that included determination of understanding of words of foreign origin, synonyms, antonyms, phraseological turns and figurative meanings and their use in own speech; mastering of word change and word formation according to grammatical standards, cited in the program on "Ukrainian language and literature", mastering of main morphological and syntactic categories in speech activity.

The analysis of the results of the tasks for understanding and use of synonyms and antonyms demonstrated complications in selection of explications for words from the active adolescent's vocabulary. Examined persons with the low speech competence formation level refused to explicate words or explicated them selectively with reluctance. At selecting synonyms, most of them named one for each word, more than a half of them demonstrated problems with selecting several ones. The overwhelming majority coped without complications with selecting antonyms to proposed words. Some pupils selected adjectives to nouns. Answers contained "russianisms", dialecticisms, slang words (ok, oho, type of and so on).

At analyzing the performed tasks, devoted to determine understanding of phraseological turns and the ability to use them in own speech, most had difficulties with explications of popular idioms, adolescents with the high communicative activity level coped better with the task. Selecting phraseological turns to wordcombinations with synonymic meanings, only one third of the examined adolescents gave high-quality answers, the quantity divided just the same between the middle and low levels.

In revealing the level of understanding of direct and figurative meanings of words, more mistakes were made in written performance, comparing with oral one. Adolescents with the low speech competence formation level performed the tasks slowly, diffidently, not correcting mistakes without a teacher's prompt.

Performing tasks for mastering word formation, most children demonstrated the high and sufficient levels, a part of them performed tasks according to the middle level, and a small number of pupils demonstrated the low level. The last group included mainly adolescents with phonetic speech disorders or low self-esteem. The quality analysis of answers fixed the absence of understanding of semantic content of a word or phrase in certain cases. As a response on the request to explicate the meaning of an invented word, adolescents cannot do it; most of them became confused, laughed. In the process of word formation some children with phonetic disorders could not understand tasks even after presenting an answer example, so looked over suffixes, placing them to a word. As the research testified, most children, who demonstrated the low level, didn't understand the mean- ing of word-forming suffixes, even created new words correctly, couldn't explain their meaning. We can assume that the passive children's vocabulary includes these words, but they are rarely used, so their meaning is not adopted that makes adolescents' speech poorer, limits it by using most widespread words of the native language.

Using the prefix method of word formation, most adolescents demonstrated the high and sufficient levels, one third demonstrated the low one. Answering the question about a change of the word meaning at adding a prefix, most pupils gave explications, but the speech of one fourth of them was phase, of predicative bases, simple, not expanded sentences.

Adolescents' answers in the task, determined the development level of understanding subject-syntactic meanings, divided as following: the high level was demonstrated by one fourth of the examined, the middle level - by three thirds, the low level was demonstrated by 10 participants. At performing the tasks, pupils made unessential mistakes and either corrected them independently or after teacher's instruction or repeated explication. Some pupils couldn't determine the correct answer variant, because considered both word combinations correct.

Most adolescents demonstrated the high and middle level and only one fourth - the low one at tasks, directed on determination of the mastering level of word change. Typical mistakes among answers for these tasks were disorders of word change of nouns in the ablative and genitive cases, most adolescents with the low level were confused with categories of noun and verbs number or performed the tasks aloud.

At checking the mastering level of word formation most pupils answered correctly, but mistakes, provoked by lack of knowledge in specific words or change of the word stems' order, occurred in answers.

Tasks for the development of harmonic speech revealed the ability to compose complex run-on sentences from simple ones. Adolescents formed also brief sentences of one word alongside with expanded complex ones. According to the tasks performance results, the group of adolescents with normal speech development divided in two equivalent parts, and only one tenth part of them demonstrated the low level.

A task was destined to determine the mastering level of native language in situations of free communication and authorized speaking. Adolescents were offered a list of topics, familiar to them, and it was necessary to express own idea according to one of them. The study demonstrated that in free communication situations one fourth of pupils mainly used simple sentences, no separating structural elements, necessary for highlighting a topic, they masked their diffidence by pauses, exclamations, use dialecticisms, words-parasites and youth slang.

At performing the tasks, the use of wordsparasites ("e-e-e", "m-m-m", "that", "and what about it", "thingy", "anyway"), unjustified pauses, motive anxiety manifestations (such as transfer and deliberate accentuation of attention on own haircut, cloth), partially conscious thinking about certain words, contemplation of oneself and even self-admiration in reflections and surrounding objects were observed in the speech of most adolescents. 


\subsection{Results of the ascertaining experiment}

The data, obtained during the three examination directions, were analyzed in detail, summarized and generalized. Comparisons of the formation levels of the lexical-grammatical component of the adolescents' speech competence under SEI gave a possibility to establish that the high formation level of this competence corresponds to $36.2 \%$ of adolescents, the middle formation level was revealed in $43.6 \%$ of adolescents, the low formation level - in $20.2 \%$.

The data, obtained at examining the lexicalgrammatical component, are presented in Table 1.

Table 1

Distribution of the studied persons by the psychological component formation indices, $\%$

\begin{tabular}{|c|c|c|c|}
\hline Number of points & Level & $\begin{array}{c}\text { Number of } \\
\text { children }\end{array}$ & $\%$ \\
\hline $81-120$ & High & 231 & 36.2 \\
\hline $41-80$ & Middle & 275 & 43.6 \\
\hline $1-40$ & Low & 128 & 20.2 \\
\hline
\end{tabular}

\section{Conclusions}

Within the work, the aim of our research was to study the speech competence formation level of younger adolescents in the educational environment of secondary school and to determine the influence of the lexicalgrammatical component on its development level. The series of tasks have been solved for attaining the aim:

1) based on the analysis of educational programs and peculiarities of speech development of younger adolescents, it has been established, that components of the speech competence included among others the lexicalgrammatical one with three criteria: general mastering of the speech lexical system; understanding of main grammatical categories of the native language; developed harmonic speech. Indicators of the first criterion were: expressive speech (active vocabulary with using an essential number of different language parts and lexicalsemantic fields, use of idioms, synonyms, antonyms, multivalent words in own speech) and impressive speech (wide passive vocabulary according to requirements of the secondary school program that are in understanding and using idioms, synonyms, antonyms, multivalent words). Indicators of the second criterion included: skilful word change; word formation level according to grammatical standards; effective use of main morphological and syntactic categories in the process of speaking activity. Indicators of the third criterion were the use of complex expanded sentences; participial constructions, comparisons; complex logical-grammatical constructions in own speech.

2) According to the separated criteria and indicators of the lexical-grammatical component of the speech competence, there has been elaborated the method of their diagnostics, including the three blocks of tasks, based on main positions and requirements of the program "Ukrainian language and literature".

3) having analyzed the obtained data, we got not only the expected result and proved the direct dependence between the low development level of the lexicalgrammatical component and its negative influence on the general level of speech competence formation, but also separated peculiarities, conditioned by psychological, individual peculiarities, educational environment influence.

According to the results of our study, among problems in the development of the lexical-grammatical component of the younger adolescents speech competence, the following abilities and skills are mastered and used especially difficultly: filling of the active vocabulary (according to age and program requirements) of nouns, verbs, adjectives and limitation of their use in speech, its unskillful use (inability to make parallels, to combine synonymic series, to explain and to use words of foreign origin); difficult mastering and use of main lexical and grammatical categories of the native language (mistakes in word change; poorness of harmonic expressions, use of dialecticisms, situational vagaries). At the same time as a result of insufficient development of the lexical-grammatical component, adolescents undergo difficulties in setting contacts, are afraid of talking about new topics and of formal communication situations, feeling own "weakness" that in its turn complicates social communication and hinders the speech personality development.

The obtained results of diagnosing the adolescents' speech competence formation condition determine elaboration of the method of younger adolescents' speech competence formation under conditions of secondary school educational environment that would have a complex character and take into account the psychological mechanism of personal development and individual development situation of younger adolescents in the system of secondary school educational environment.

\section{References}

1. Pro Natsionalnu stratehiiu rozvytku osvity v Ukraini na period do 2021 roku (2013). Ukaz Prezydenta Ukrainy No. 344/2013. 25.06.2013. Available at: https://zakon.rada.gov.ua/laws/show/344/2013\#Text

2. Pro osnovni kompetentsii dlia navchannia protiahom usoho zhyttia (2006). Rekomendatsiia 2006/962/YeS Yevropeiskoho Parlamentu ta Rady (YeS). 18.12.2006. Available at: https://zakon.rada.gov.ua/laws/show/994_975\#Text

3. Nikolaieva, S. Yu. (Ed.) (2003). Zahalnoievropeiski Rekomendatsii z movnoi osvity: vyvchennia, vykladannia, otsiniuvannia. Kyiv: Lenvit, 273.

4. Makhinov, V. (2015). Rozvytok profesiinoho movlennia studentiv yak zasib formuvannia movnoi osobystosti maibutnoho vchytelia. Pedahohika vyshchoi ta serednoi shkoly, 44, 84-91.

5. Hubar, O. (2018). Pereoriientatsiia zmistu lohopedychnoi roboty z pidlitkom v umovakh hlobalizatsiinykh protsesiv. Vytoky pedahohichnoi maisternosti. Poltava, 22, 68-73.

6. Kalmykova, L. O., Kalmykov, H. V., Lapshyna, I. M., Kharchenko, N. V; Kalmykova, L. O. (Ed.) (2008). Psykholohiia movlennia i psykholinhvistyka: Navchalnyi posibnyk dlia studentiv vyshchykh navchalnykh zakladiv. Kyiv: PereiaslavKhmelnytskyi pedahohichnyi instytut, v-vo "Feniks", 245. 
7. Kasianova, O. V. (2011). Formuvannia komunikatyvnoi kompetentnosti molodshykh pidlitkiv u hromadskykh dytiachykh obiednanniakh. Kyiv: Instytut problem vykhovannia NAPN Ukrainy, 21.

8. Tsaryk, O. M. (2015). Metodychni aspekty formuvannia kultury movlennia u shkolakh Halachyny mizhvoiennoho periodu KhKh st. Naukovyi visnyk Uzhhorodskoho natsionalnoho universytetu. Seriia: Pedahohika. Sotsialna robota, 37, 189-192.

9. Stefanyshyn, K. (2017). Robota nad pryimennykom u 5 klasi yak pidhotovchyi etap do usvidomlennia yoho komunikatyvnoi roli u strukturi movlennia. Naukovyi visnyk Uzhhorodskoho natsionalnoho universytetu. Seriia : Pedahohika. Sotsialna robota, 1 (40), 276-278.

10. 10.Van Ek, J. A. (1986). Objectives for foreign language learning. Vol. 1: Scope. Strasbourg Council of Europe Press, 89.

11. Pentyliuk, M., Bakum, Z., Horoshkina, O., Karaman, S., Karaman, O. et. al.; Pentyliuk, M. (Ed.) (2011). Praktykum z metodyky navchannia ukrainskoi movy v zahalnoosvitnikh zakladakh: modulnyi kurs. Kyiv: Lenvit, 366.

12. Kalinina, L. M., Meleshko, V. V., Osadchyi, I. H., Parashchenko, L. I., Topuzov, M. O.; Kalinina, L. M. (Ed.) (2018). Upravlinnia vsebichnymy navchalnymy zakladamy yak aktyvnymy systemamy: modeli ta mekhanizmy. Kyiv: Pedahohichna dumka, 224.

13. Holub, N. (2008). Rytoryka u vyshchii shkoli:monohrafiia. Cherkasy: Brama Ukrainy, 318.

14. Kostolovych, T. V. (2019). Formuvannia komunikatyvnoi kompetentnosti maibutnikh uchyteliv ukrainskoi movy i literatury u protsesi navchannia fonetyky y orfoepii. Kyiv: Kyivskyi universytet imeni Borysa Hrinchenka, 24.

15. Chebotarova, I. O. (2018). Formuvannia komunikatyvnoi kompetentnosti maibutnikh kerivnykiv zakladiv osvity v umovakh mahistratury. Kharkiv: Ukrainska inzhenerno-pedahohichna akademiia, 26.

16. Prohramy dlia zahalnoosvitnikh navchalnykh zakladiv «Ukrainska mova. 5-12 klasy» Lyst MON vid 23.12.2004 No. 1/11-6611. Kyiv: Rerun, 192.

Received date 28.12.2020

Accepted date 22.01.2021

Published date 30.01.2021

Olha Hubar, Senior Lecturer, Department of Special Education and Social Work, Poltava V. G. Korolenko National Pedagogical University, Ostrohradskoho str., 2, Poltava, Ukraine, 36000

E-mail: olhahubar82@ukr.net 